\title{
PENGARUH PENERAPAN STUDENTS TEAM ACHIEVEMENT DIVISIONS UNTUK MENGEMBANGKAN SIKAP RAMAH LINGKUNGAN DI SD SENDANGADI 1
}

\section{THE EFFECTS OF THE APPLICATION OF THE STUDENTS TEAM ACHIEVEMENT DIVISIONS (STAD) TYPE ON THE DEVELOPMENT OF ENVIRONMENT-FRIENDLY ATTITUDES IN SD SENDANGADI 1}

\author{
Septiyati Purwandari, Siti Partini Suardiman \\ Lembaga Pendidikan Anak "Rumahku Tumbuh", Universitas Negeri Yogyakarta \\ septiyatipurwandari@yahoo.com, -
}

\begin{abstract}
Abstrak
Penelitian ini bertujuan untuk mengetahui pengaruh model pembelajaran STAD untuk mengembangkan sikap ramah lingkungan siswa SD Sendangadi 1 Mlati Sleman Yogyakarta. Metode penelitian eksperimen kuasi pola nonequivalent control group design. Subjek penelitian siswa kelas V SD Sendangadi I tahun ajaran 2011/2012. Data hasil penelitian diolah melalui program SPSS for windows dengan uji Paired Sample t-test. Hasil penelitian menunjukkan bahwa hasil belajar IPS pada group eksperimen dengan menggunakan model pembelajaran kooperatif tipe STAD lebih baik dibandingkan dengan group kontrol. Hal ini ditunjukkan dengan perolehan rata-rata posttes setelah eksperimen sebesar 68.03 sedangkan pretes sebelum eksperimen diperoleh hasil rata-rata tes sebesar 63.91. Nilai signifikan equal variances assumed dari hasil belajar kurang dari 0,05 yaitu 0.000 . Hal ini berarti terdapat pengaruh penggunaan model pembelajaran kooperatif tipe STAD dalam pembelajaran IPS Berwawasan Lingkungan untuk mengem-bangkan sikap ramah lingkungan.
\end{abstract}

Kata Kunci: IPS, Wawasan Lingkungan, Sikap, Lingkungan hidup

\begin{abstract}
This study aims to investigate the effect of STAD type on development of environment-friendly attitudes of the students of SD Sendangadi 1. This was a quasi-experimental study employing the nonequivalent control group design. The research subjects were Grade V students of SD Sendangadi 1 in the academic year of 2011/2012. The research data were processed by means of the program of SPSS for Windows, namely the paired samples t-test. The results of the study show that a posttest mean of 68.03 after the experiment while the Pretest mean before the experiment is 63.91. The significance value of the equal variances assumed of the Social Studies learning outcomes was less than 0.05, namely 0.000; this indicates that there is an effect of the application of the STAD type on the environment-perspective Social Studies learning to develop environment-friendly attitudes among Grade $V$ students of SD Sendangadi 1.
\end{abstract}

Keywords: social studies, environment perspective, attitudes, environment 


\section{Pendahuluan}

Lingkungan adalah komponen yang diperlukan bagi kehidupan manusia, sehingga manusia dan lingkungan adalah sebagai satu kesatuan yang tidak dapat dipisahkan dan memiliki hubungan yang saling berkaitan. Kerusakan lingkungan hidup akibat aktivitas manusia pada umumnya disebabkan oleh ketidaktahuan masyarakat terhadap akibat dari tindakannya, desakan kebutuhan hidup, kurangnya pengetahuan tentang ekosistem, kepedulian yang rendah terhadap kelestarian lingkungan, dan kurang memasyarakatnya hukum tentang lingkungan hidup (Suranto \& Kusrahmadi, 2003, p.133).

Jalur pendidikan merupakan usaha untuk mencapai terwujudnya masyarakat yang memiliki sikap dan perilaku berwawasan lingkungan. Melalui proses belajar, terjadi proses komunikasi dan transfer pengetahuan dan nilai. Dengan demikian, kunci utama sikap terletak pada proses kognisi dalam belajar siswa. Penerapan STAD dalam pembelajaran ini merupakan upaya pembinaan kesadaran terhadap manfaat pelestarian ekosistem lingkungan hidup. Melalui model pembelajaran kooperatif tipe STAD siswa mengkonstruksi pengetahuan secara mandiri, sehingga dari kegiatan tersebut siswa merasa lebih perduli terhadap lingkungan, yang akhirnya dapat membentuk sikap dan perilaku positif terhadap lingkungan (Mahanal, 2009, p.35).

Pendidikan berwawasan lingkungan dapat dibentuk melalui pemberdayaan mata pelajaran yang sudah ada. Demikian juga dengan mata pelajaran IPS yang berwawasan lingkungan dapat disajikan dengan terpadu, interdisipliner atau secara eksklusif dikaji berdasarkan disiplin ilmu tertentu.

Setiap anak memiliki potensi kecerdasan yang berbeda-beda, untuk itu perlu dikembangkan model pembelajaran khususnya pada mata pelajaran IPS, salah satunya adalah dengan menerapkan model pembelajaran kooperatif tipe Student Teams Achievement Divitions (STAD) yang merupakan tipe pembelajaran kooperatif sederhana dengan lima tahapan pembelajaran (Roy Killen, 2006, p.195).

Siswa SD Sendangadi 1 Mlati Sleman belum mampu menguasai kompleksitas permasalahan lingkungan hidup. Berdasarkan studi pendahuluan yang dilakukan peneliti pada bulan September 2012, ditemukan hasil bahwa metode pembelajaran yang digunakan masih menggunakan metode pembelajaran konvensional.

Melalui pendekatan kooperatif tipe STAD ini, diharapkan pembinaan kesadaran siswa terhadap lingkungan hidup dalam upaya menyelesaikan masalah-masalah lingkungan dapat diberikan dengan lebih efektif dan efisien, sehingga menumbuhkan sikap ramah lingkungan pada siswa sedini mungkin.

\section{Model Pembelajaran Kooperatif Tipe STAD}

Pembelajaran kooperatif tipe STAD yang dikembangkan oleh Slavin (1995) merupakan pembelajaran kooperatif yang paling sederhana yang menekankan pada aktivitas dan interaksi diantara siswa untuk saling memotivasi dan membantu dalam memahami suatu materi pelajaran. Slavin (2005, p.143) menyatakan langkah-langkah pembelajaran tipe STAD meliputi: Tahapan I: presentasi kelas, Tahapan II: belajar kelompok, Tahapan III: Kuis, Tahapan IV: peningkatan Individu, dan Tahapan V: penghargaan kelompok.

Keunggulan dan kelemahan model pembelajaran kooperatif tipe STAD menurut Roestiyah (2001, p.17) adalah: 1) Memberikan kesempatan kepada siswa untuk menggunakan keterampilan bertanya dan membahas suatu masalah; 2) Memberikan kesempatan kepada siswa untuk lebih intensif mengadakan penyelidikan mengenai suatu masalah; 3) Mengembangkan bakat kepemimpinan dan mengajarkan keterampilan berdiskusi; 4) Memungkinkan guru untuk lebih memperhatikan siswa sebagai individu dan kebutuhan belajarnya; 5) Para siswa lebih aktif bergabung dalam pelajaran mereka dan mereka lebih aktif dalam berdiskusi; 6) Memberikan kesempatan kepada siswa untuk mengembangkan rasa menghargai, menghormati pribadinya, dan menghargai pendapat orang lain.

Adapun kelemahannya adalah kerja kelompok hanya melibatkan mereka yang mampu memimpin dan mengarahkan mereka yang kurang pandai dan kadang-kadang menuntut tempat yang berbeda dan gaya-gaya mengajar berbeda.

\section{Pembelajaran IPS SD}

IPS adalah bidang studi yang mempelajari, menelaah, menganalisis gejala dan masalah sosial di masyarakat dengan meninjau dari berbagai perpaduan aspek kehidupan (Bruce dalam Winataputra, 2009, p.89). Arah mata pelajaran IPS ini dilatarbelakangi oleh pertimbang- 
an bahwa di masa yang akan datang peserta didik akan menghadapi tantangan berat karena kehidupan masyarakat global selalu mengalami perubahan setiap saat.

Oleh karena itu, mata pelajaran IPS dirancang untuk mengembangkan pengetahuan, pemahaman dan kemampuan analisis terhadap kondisi sosial masyarakat dalam memasuki kehidupan bermasyarakat dinamis (Mason et al, 2000 , p.6). Untuk itulah IPS harus dapat berperan bagi anak didik dalam mengembangkan berbagai aspek kehidupan di dalam masyarakat.

Ruang lingkup pembelajaran IPS SD meliputi segala sesuatu yang ada dan terjadi di sekitar anak sejak dari keluarga, sekolah, desa, kecamatan sampai lingkungan yang luas negara dan dunia dengan berbagai permasalahannya, kegiatan manusia, lingkungan geografi dan budaya, kehidupan masa lampau, perkembangan kehidupan manusia, dan anak sebagai sumber materi meliputi berbagai segi.

\section{Pendidikan Berwawasan Lingkungan Hidup}

Pendidikan berwawasan lingkungan hidup adalah upaya mengubah perilaku dan sikap yang dilakukan oleh berbagai pihak atau elemen masyarakat yang bertujuan untuk meningkatkan pengetahuan, keterampilan dan kesadaran masyarakat tentang nilai-nilai lingkungan dan isu permasalahan lingkungan yang pada akhirnya dapat menggerakkan masyarakat untuk berperan aktif dalam upaya pelestarian dan keselamatan lingkungan untuk kepentingan generasi sekarang dan yang akan datang (Efrat \& Tamar, 2012, p.2212).

Pendidikan berwawasan lingkungan tidak hanya pemahaman tentang perlunya keseimbangan hubungan antarmakhluk hidup dengan alamnya, tetapi juga untuk meningkatkan sikap dan nilai positif terhadap permasalahan lingkungan, sehingga mendorong peserta didik melakukan beberapa bentuk perbuatan langsung.

\section{Sikap Ramah Lingkungan}

Menurut Azwar (2005, p.23), sikap mempunyai tiga komponen yang saling menunjang yaitu kognitif, afektif, dan konasi. Faktor yang mempengaruhi pembentukan sikap adalah pengalaman pribadi, kebudayaan, media massa, pe-ngaruh orang lain yang dianggap penting, lembaga Pendidikan dan lembaga agama, faktor emosional, dan pengetahuan.

Sadar lingkungan dapat dibentuk dan dikembangkan dengan cara menghadapkan se- seorang pada persoalan lingkungan sekitar secara terus-menerus, menumbuhkan budaya malu untuk melakukan kegiatan antara lain: mengotori tempat umum dan tempat orang lain, membuang sampah dan polutan di sembarang tempat, dan memutuskan rantai kehidupan (Tim \& Gail, 2005, p.11).

Pengukuran sikap individu yang ramah terhadap lingkungan dalam penelitian ini adalah, mengacu pada New Ecological Paradigm Scale for children (NEP Scale) yang dibuat oleh Riley E Dunlap dan Kent D. Van Liere pada tahun 1978 dan mengalami revisi pada tahun 2000.

\section{Karakteristik Siswa SD}

Anak besar merupakan anak pada usia Sekolah Dasar yaitu antara 6 tahun sampai 12 tahun (Tisnowati Tamat dan Moekarto Mirman, 2005, p.479). Lebih lanjut menurut Siti Partini (1995, p.116), ciri khas anak pada masa kelas tinggi Sekolah Dasar adalah perhatiannya tertuju kepada kehidupan praktis sehari-hari, ingin tahu, ingin belajar, realistis, timbul minat kepada pelajaran-pelajaran khusus, anak memandang nilai sebagai ukuran yang tepat mengenai prestasi belajarnya di sekolah, dan anak-anak suka membentuk kelompok sebaya atau peergroup untuk bermain bersama, dan mereka membuat peraturan sendiri dalam kelompoknya.

\section{Metode}

Metode penelitian yang digunakan dalam penelitian ini adalah eksperimen kuasi dengan pola nonequivalent control group design (Pretest-postest yang tidak ekuivalen). Eksperimen itu sendiri adalah observasi di bawah kondisi buatan (artificial condition) dimana kondisi tersebut dibuat dan diatur oleh si peneliti (Sugiyono, 2007, p.116). Langkahlangkah penelitian meliputi (1) Preeksperiment measurenment (pengukuran sebelum perlakuan), (2) Treatment (tindakan pelaksanaan eksperimen), dan (3) Post eksperiment measurenment (pengukuran sesudah eksperimen berlangsung) (Sutrisno Hadi, 2004, pp.468-469).

Penelitian ini dilakukan di SD Sendangadi I Kabupaten Sleman, pada semester II tahun ajaran 2011/2012. Populasi dalam penelitian ini adalah siswa kelas V SD Sendangadi I Kabupaten Sleman yang berjumlah 63 siswa dan dibagi dalam dua kelas yaitu kelas VA dan VB. Kelas VA dengan jumlah siswa 33 anak terpilih menjadi kelompok eksperimen, dan ke- 
las VB dengan jumlah 30 anak menjadi kelompok kontrol.

Teknik pengumpulan data yaitu cara yang digunakan untuk mengumpulkan atau memperoleh data dalam suatu penelitian. Teknik yang digunakan untuk mengetahui kesejajaran adalah teknik korelasi product moment yang dikemukakan Pearson (David, 2011, p.34). Sebelum melakukan pengumpulan data, instrumen terlebih dahulu diujicobakan di sekitar lingkungan tempat tinggal peneliti. Instrumen tesebut terdiri atas 20 butir pertanyaaan dan diujicobakan kepada 33 Siswa Kelas V yang memiliki karakteristik yang sama dengan responden. Uji reliabilitas dalam penelitian ini dilakukan dengan bantuan SPSS 19,0 dan kri- teria untuk menentukan tingkat reliabilitas instrument digunakan pedoman yang dikemukakan oleh Nisfiannoor (2009, p.252). Teknik analisis data dalam penelitian ini meliputi uji normalitas dan uji hipotesis (Paired sample t-test).

\section{Hasil dan Pembahasan}

\section{Deskrpsi Data Hasil Pretest dan Posttest}

Perolehan nilai rata-rata kelas eksperimen lebih tinggi dibandingkan dengan perolehan nilai rata-rata kelas kontrol. Ringkasan hasil pretest dan posttest pada pembelajaran IPS berwawasan lingkungan materi keanekaragaman alam Indonesia yang dicapai siswa kelas kontrol dan kelas eksperimen adalah:

Tabel 1. Deskripsi Data Hasil Pretest dan Posttest

\begin{tabular}{clcccc}
\hline No & Variabel & Minimum & Maksimum & Mean & Std Deviasi \\
\hline 1 & Pretest Eksperimen & 53 & 74 & 63,91 & 5,19 \\
2 & Posttest Eksperimen & 57 & 74 & 68,03 & 3,74 \\
3 & Pretest Kontrol & 51 & 70 & 62,23 & 4,33 \\
4 & Posttest Kontrol & 55 & 69 & 61,40 & 3,25 \\
\hline
\end{tabular}

Deskripsi Data Hasil Uji Normalitas

Angket hasil pembelajaran IPS telah berdistribusi normal. Adapun hasil uji normali- tas data pretest dan posttest pada kelas eksperimen dan kelas kontrol adalah sebagai berikut:

Tabel 2. Hasil Uji Normalitas Data Angket Kelas Ekperimen dan Kontrol

\begin{tabular}{clccc}
\hline No & \multicolumn{1}{c}{ Variabel } & Nilai Z Hitung & Sig & Keterangan \\
\hline 1 & Pretest Eksperimen & 0,433 & 0,992 & Berdistribusi Normal \\
2 & Posttest Eksperimen & 0,545 & 0,928 & Berdistribusi Normal \\
3 & Pretest Kontrol & 0,613 & 0,847 & Berdistribusi Normal \\
4 & Posttest Kontrol & 0,485 & 0,973 & Berdistribusi Normal \\
\hline
\end{tabular}

Deskripsi Pelaksanaan Pembelajaran pada Kelompok Kontrol dan Eksperimen

Kelas kontrol merupakan kelas yang diajar menggunakan metode pembelajaran konvensional atau kelas yang tidak diberi perlakuan penerapan model pembelajaran kooperatif tipe STAD. Subjek pada kelas kontrol sebanyak 30 siswa pada kelas VB SD Negeri Sendangadi Sleman, Yogyakarta. Pelaksanaan pembelajaran di kelas kontrol dilakukan dengan dua kali pertemuan dengan menggunakan metode pembelajaran konvensional.

Kelas eksperimen merupakan kelas yang akan diberikan model pembelajaran kooperatif tipe STAD. Banyak siswa yang ada pada kelas eksperimen ini berjumlah 33 siswa. Pelaksanaan penelitian dimulai dari mengidentifikasi masalah di lapangan dengan melakukan wawancara kepada guru kelas V SDN Sendangadi I. Setelah menemukan permasalahan di lapangan, langkah selanjutnya yang dilaku- kan adalah menyusun proposal penelitian, membuat surat ijin penelitian, membuat instrumen penelitian, menyusun RPP (Rencana Pelaksanaan Pembelajaran) untuk melakukan eksperimen, serta melakukan uji coba terhadap instrumen penelitian yang akan digunakan.

Tahap selanjutnya yang dilakukan peneliti adalah melakukan pengambilan data awal untuk mengetahui hasil belajar sebelum dilakukan eksperimen dengan materi kenampakkan alam Indonesia. Tahapan selanjutnya adalah memberi perlakukan eksperimen kepada kelas tersebut. Pembelajaran yang dilakukan dengan memberi perlakuan menggunakan model pembelajaran kooperatif tipe STAD. Materi pembelajaran yang digunakan adalah tentang kenampakkan alam Indonesia.

Selama proses pembelajaran berlangsung, peneliti melakukan pengamatan terhadap penggunaan strategi pembelajaran STAD. Pengamatan dilakukan melalui lembar observasi 
yang di dalamnya memuat panduan selama pembelajaran berlangsung yang telah disesuaikan dengan langkah-langkah strategi pembelajaran STAD. Observasi ini digunakan untuk melihat keefektifan dari penggunaan strategi pembelajaran STAD. Observasi ini meliputi observasi aktivitas guru dan aktivitas siswa.

Pemberian nilai pada setiap aktivitas siswa ditujukan sebagai penilaian proses, sedangkan penilaian hasil diperoleh dari nilai tes formatif. Untuk mengetahui keefektifan pembelajaran dapat diketahui dengan melihat nilai proses dan nilai hasil yang dinamakan oleh peneliti dengan hasil belajar (Tes ke-2). Setelah proses eksperimen selesai, dilakukan analisa statistik dari data yang telah terkumpul yang merupakan hasil belajar selama pembelajaran untuk kemudian disusun dalam bentuk laporan penelitian.

Observasi aktivitas guru pertemuan ke-1 menunjukkan bahwa ada 14 indikator yang telah dilaksanakan oleh guru sesuai dengan lembar observasi aktivitas guru. Indikator tersebut meliputi melakukan apersepsi, menginformasikan tujuan pembelajaran, menginformasikan langkah-langkah pembelajaran dengan menggunakan model pembelajaran kooperatif tipe STAD, membagi siswa menjadi 6 kelompok, memberikan materi kepada siswa, memberikan kesempatan kepada siswa untuk menyimak materi yang diberikan, memberikan kesempatan kepada siswa untuk belajar bersama dalam kelompok, membimbing siswa dalam belajar kelompok materi, membagikan LKS, memberikan kesempatan kepada kelompok untuk menyelesaikan LKS, membimbing siswa dalam melakukan diskusi untuk menyelesaikan LKS, memberikan kesempatan kepada siswa untuk saling membantu dalam menguasai materi yang dipelajari, membimbing siswa untuk membuat rangkuman, memberikan kuis kepada siswa secara individual, memberikan penghargaan kelompok, mengelola waktu secara efisien, menggunakan media secara efektif dan efisien, dan penggunaan bahasa dalam pembelajaran. Observasi aktivitas guru pertemuan ke-2 menunjukkan bahwa ada 14 indikator yang telah dilaksanakan oleh guru sesuai dengan lembar observasi aktivitas guru.

Berdasarkan hasil observasi aktivitas siswa, pada pertemuan pertama diperoleh hasil skor mulai dari 1-4. Pada indikator kesiapan da-lam mempersiapkan buku catatan terdapat 33 siswa mendapat skor 4. Dengan demikian dapat disimpulkan bahwa semua siswa di kelas ter-sebut sudah baik dalam mempersiapkan buku catatan dan buku pelajaran. Pada indikator menempati tempat yang telah ditetapkan sesuai dengan kelompok, siswa-siswa dalam satu kelompok terdapat 33 siswa yang mendapat skor 4. Siswa dalam kelas tersebut sudah mau menerima siapa yang menjadi anggota kelompoknya sesuai dengan yang ditetapkan oleh guru. Pada indikator menyimak penjelasan mengenai langkah pembelajaran, terlihat ada 2 siswa dengan yang kurang menyimak saat guru menjelaskan, 4 siswa yang menyimak dan 27 siswa yang menyimak dengan sungguhsungguh langkah-langkah yang disampaikan guru. Pada indikator menyimak materi pembelajaran yang diberikan guru, terdapat 3 siswa yang kurang menyimak materi, 2 siswa yang menyimak materi dan 28 siswa yang menyimak materi dengan serius. Jadi siswa di kelas tersebut pada dasarnya senang untuk mempelajari materi pembelajaran.

Pada indikator kecepatan dalam menguasai materi, ada 5 siswa yang membutuhkan waktu cukup lama untuk menguasai materi, 8 siswa dengan yang membutuhkan waktu cukup untuk menguasai materi dan 17 siswa menguasai materi dengan tepat sesuai dengan waktu yang ditetapkan. Pada indikator menyimak pertanyaan yang diberikan guru dalam LKS ada 3 siswa kurang menyimak pertanyaan yang ada pada LKS, 4 siswa menyimak pertanyaan dalam LKS dan 26 siswa menyimak pertanyaan guru yang ada dalam LKS dengan serius.

Pada indikator aktif dalam mencari tahu jawaban yang ada pada LKS terdapat 6 siswa yang masih menggantungkan dengan jawaban teman sekelompok, 11 siswa yang mau mencari jawaban dari pertanyaan yang ada pada LKS, namun kurang tepat dan 16 siswa yang aktif mencari jawaban dari pertanyaan yang ada pada LKS dengan tepat. Pada indikator diskusi dengan teman satu kelompok untuk menyelesaikan LKS, terdapat 5 siswa mau berdiskusi namun tidak sungguh-sungguh dan 28 siswa mau berdiskusi dengan sungguh-sungguh untuk menyelesaikan LKS.

Pada indikator berani aktif dalam menjelaskan materi yang sudah dipahami dalam kelompok terdapat 3 siswa yang takut dalam menjelaskan materi yang sudah dipahami kepada teman sekelompok, 19 siswa yang aktif namun kurang yakin saat menjelaskan kepada teman satu kelompok dan terdapat 12 siswa yang aktif dan berani dalam menyampaikan 
materi yang sudah dipahami kepada teman satu kelompok.

Pada indikator kejelasan saat menerangkan materi kepada teman, terdapat 18 siswa menjelaskan dengan jelas, namun kurang sempurna sedangkan 15 siswa dapat menjelaskan dengan runtut dan singkat kepada teman satu kelompok tentang materi yang sudah dipahaminya. Pada indikator membuat rangkuman tentang materi yang dipelajarinya terdapat 2 siswa yang membuat rangkuman namun kurang lengkap dan 31 siswa membuat rangkuman dengan lengkap dan rapi pada buku catatannya. Pada Indikator mengerjakan kuis secara individu, terdapat 3 siswa yang mengerjakan soal, namun masih melirik dari jawaban teman sebelahnya dan ada 30 siswa mengerjakan soal secara individu.

Pada pertemuan kedua, indikator penggunaan bahasa dalam pembelajaran, terdapat 4 siswa yang menggunakan bahasa Indonesia namun masih kurang sempurna, sedangkan 29 siswa telah menggunakan bahasa Indonesia dengan benar dan tepat. Selanjutnya indikator yang terakhir yaitu penggunaan waktu yang ditentukan terdapat 3 siswa masih menggunakan waktu yang lama untuk menguasai materi dan mengerjakan soal, 26 siswa menggunakan waktu yang cukup untuk menguasai materi dan mengerjakan soal namun kurang tepat dan 4 siswa siswa mengerjakan soal dan menguasai materi dengan waktu yang singkat. Pada indikator kesiapan dalam mempersiapkan buku catatan terdapat 3 siswa mendapat skor 3 dan 30 siswa mendapat skor 4 Dengan demikian dapat disimpulkan bahwa lebih dari sebagian siswa di kelas tersebut sudah baik dalam mempersiapkan buku catatan dan buku pelajaran.

Pada indikator menempati tempat yang telah ditetapkan sesuai dengan kelompok, siswa-siswa dalam satu kelompok terdapat 2 siswa yang mendapat skor 3 dan 30 siswa mendapat skor 4. Siswa dalam kelas tersebut sudah mau menerima siapa yang menjadi anggota kelompoknya, hanya 2 siswa saja yang kurang senang dengan kelompok yang ditetapkan oleh guru. Pada indikator menyimak penjelasan mengenai langkah pembelajaran, terlihat 5 siswa yang menyimak dan 26 siswa yang menyimak dengan sungguh-sungguh langkahlangkah yang disampaikan guru.

Pada indikator menyimak materi pembelajaran yang diberikan guru, terdapat 1 siswa yang kurang menyimak materi, 4 siswa yang menyimak materi dan 28 siswa yang menyi- mak materi dengan serius. Jadi siswa di kelas tersebut pada dasarnya senang untuk mempelajari materi pembelajaran. Pada indikator kecepatan dalam menguasai materi, ada 6 siswa yang membutuhkan waktu cukup untuk menguasai materi dan 27 siswa menguasai materi dengan tepat sesuai dengan waktu yang ditetapkan. Pada indikator menyimak pertanyaan yang diberikan guru dalam LKS ada 1 siswa menyimak pertanyaan dalam LKS dan 32 siswa telah menyimak pertanyaan guru yang ada dalam LKS dengan serius.

Pada indikator aktif dalam mencari tahu jawaban yang ada pada LKS terdapat 4 siswa yang mau mencari jawaban dari pertanyaan yang ada pada LKS, namun kurang tepat dan 29 siswa yang aktif mencari jawaban dari pertanyaan yang ada pada LKS dengan tepat. Pada indikator diskusi dengan teman satu kelompok untuk menyelesaikan LKS, terdapat 1 siswa mau berdiskusi namun tidak sungguhsungguh dan 32 siswa telah mau berdiskusi dengan sungguh-sungguh untuk menyelesaikan LKS.

Pada indikator berani aktif dalam menjelaskan materi yang sudah dipahami dalam kelompok terdapat 4 siswa yang aktif namun kurang yakin saat menjelaskan kepada teman satu kelompok dan terdapat 29 siswa yang aktif dan berani dalam menyampaikan materi yang sudah dipahami kepada teman satu kelompok. Pada indikator kejelasan saat menerangkan materi kepada teman, terdapat 1 siswa yang menjelaskan dengan jelas, namun kurang sempurna sedangkan 32 siswa dapat menjelaskan dengan runtut dan singkat kepada teman satu kelompok tentang materi yang sudah dipahaminya.

Pada indikator membuat rangkuman tentang materi yang dipelajarinya terdapat 5 siswa yang membuat rangkuman namun kurang lengkap dan 28 siswa membuat rangkuman dengan lengkap dan rapi pada buku catatannya. Pada Indikator mengerjakan kuis secara individu, terdapat 1 siswa yang mengerjakan soal, namun masih melirik dari jawaban teman sebelahnya dan ada 32 siswa yang mengerjakan soal secara individu. Pada indikator penggunaan bahasa dalam pembelajaran, terdapat 2 siswa yang menggunakan bahasa Indonesia namun masih kurang sempurna sedangkan 31 siswa telah menggunakan bahasa Indonesia dengan benar dan tepat. Selanjutnya indikator yang terakhir yaitu penggunaan waktu yang ditentukan terdapat 7 siswa menggunakan 
waktu yang cukup untuk menguasai materi dan mengerjakan soal namun kurang tepat dan 26 siswa mengerjakan soal dan menguasai materi dengan waktu yang singkat.

Berdasarkan data hasil observasi aktifitas siswa pada pertemuan ke-1 dan pertemuan ke-2 menunjukkan adanya perkembangan keaktifan siswa dalam menerapkan strategi pembelajaran STAD yang semakin baik sesuai dengan langkah-langkah pembelajaran STAD.

Hasil Belajar IPS Berwawasan Lingkungan pada Kelompok Kontrol dan Ekperimen

Perhitungan uji beda dengan bantuan SPSS 19,0 menggunakan Paired sampel t-tes bertujuan untuk melihat perbedaan rata-rata hasil belajar IPS dan sikap ramah lingkungan antara Pretest dan posttest baik yang tidak dikenai model pembelajaran kooperatif tipe STAD maupun yang diberlakukan model pembelajaran kooperatif tipe STAD.

Hasil uji statistik yang dilakukan dengan bantuan SPSS for windows didapatkan nilai $t$ hitung pada uji paired sampel seperti yang tertera pada Tabel 3 berikut ini

Tabel 3. Hasil Uji Paired Sampel Test Statistik

\begin{tabular}{lccccc}
\hline Variabel & $\begin{array}{c}\mathbf{t} \\
\text { hitung }\end{array}$ & $\begin{array}{c}\mathbf{t} \\
\text { tabel }\end{array}$ & df & Sig & Ket \\
\hline $\begin{array}{l}\text { Pretest- } \\
\begin{array}{l}\text { Posttest } \\
\text { Kontrol }\end{array}\end{array}$ & 1,078 & 2,045 & 29 & 0,290 & $\begin{array}{c}\text { Tidak } \\
\text { sig }\end{array}$ \\
$\begin{array}{l}\text { Pretest }- \\
\begin{array}{l}\text { Posttest } \\
\text { Ekperimen }\end{array}\end{array}$ & $-4,690$ & 2,036 & 32 & 0,000 & Sig \\
\hline
\end{tabular}

Berdasarkan uji statistik melalui program SPSS 19 nilai t hitung pada kelas kontrol adalah sebesar 1,078 dengan sig 0,290. Oleh karena sig yang dihasilkan lebih dari taraf kesalahan 5\% maka dapat disimpulkan bahwa rata-rata hasil tes pada Pretest dan posttes di kelas kontrol adalah sama. Dengan demikian dapat dinyatakan bahwa pembelajaran melalui metode konvensional di kelas kontrol pada mata pelajaran IPS yang berwawasan lingkungan belum mampu menumbuhkan sikap ramah terhadap lingkungan hidup yang dimiliki oleh siswa kelas V SD Sendangadi I Sleman Yogyakarta.

Lain halnya hasil uji paired pada kelas eksperimen. Hasil uji t paired sampel menghasilkan nilai $\mid \mathrm{t}$ hitung $\mid=4,690$ yang lebih dari nilai t tabel. Kriteria keputusan ini dapat pula dengan mem-bandingkan antara nilai sig yang diper-oleh dengan taraf kesalahan. Nilai sig = 0,000 kurang dari taraf kesalahan 5\% sehingga dapat disimpulkan tolak Ho dan dinyatakan bahwa model pembelajaran STAD pada mata pelajaran IPS yang berwawasan lingkungan mampu menumbuhkan sikap ramah terhadap lingkungan hidup yang dimiliki oleh siswa kelas V SD Sendangadi I Sleman Yogyakarta.

Setelah diketahui adanya perbedaan hasil Pretest dan posttest baik pada kelas eksperimen maupun kelas kontrol maka untuk selanjutnya dilakukan uji $t$ independen sampel. Hal ini bertujuan untuk mengetahui apakah terdapat perbedaan antara kelas eksperimen dan kontrol sebelum dan sesudah perlakuan. Untuk dapat melakukan uji hipotesis ini maka perlu pula dicek homogenitas antarkelompok. Uji homogenitas menggunakan levene's tets. Berikut ini hasil dari uji homogenitas untuk data hasil belajar IPS wawasan lingkungan disajikan pada Tabel 4.

Tabel 4. Hasil Uji Homogenitas Data Pembelajaran IPS

\begin{tabular}{cccc}
\hline Data & F hitung & Sig & Ket. \\
\hline Pretest KK-KE & 1,074 & 0,304 & Homogen \\
Posttest KK-KE & 0,417 & 0,521 & Homogen \\
\hline
\end{tabular}

Setelah diketahui bahwa data telah normal dan homogen selanjutnya dapat dilakukan uji hipotesis untuk mengetahui ada tidaknya perbedaan antara kelas kontrol dan kelas eksperimen baik pada Pretest maupun pada posttest. Hasil dari uji t independen sampel ditunjukkan pada Tabel 5 berikut ini:

Tabel 5. Hasil Uji t Data Pretest dan Posttest Kelompok Kontrol dan Ekperimen

\begin{tabular}{ccccc}
\hline Data & t hitung & df & Sig & Ket. \\
\hline Pretest KK-KE & 1,385 & 61 & 0,171 & Tidak \\
Pig \\
Posttest KK-KE & 7,475 & 61 & 0,000 & Sig \\
\hline
\end{tabular}

Hasil yang disajikan pada Tabel 5 menunjukkan nilai sig sebesar 0,171 untuk data pretest. Nilai ini tidak sig pada taraf kesalahan 5\% sehingga dapat disimpulkan Ho diterima. Artinya tidak ada perbedaan antara kelas kontrol dan kelas eksperimen pada kemampuan awal. Kemampuan awal antara kedua kelas dapat dikatakan sama. Oleh karena adanya kesamaan tersebut maka kelas eksperimen diberikan perlakukan yang kemudian dibandingkan hasilnya. Apakah terdapat pengaruh terhadap hasil pembelajaran oleh adanya metode yang diterapkan.

Setelah dilakukan perlakuan pada kelas eksperimen kemudian kedua kelas diberikan tes kembali. Hasil posttest ini diperoleh 
nilai sig $=0,000$ yang kurang dari taraf kesalahan 5\% sehingga disimpulkan bahwa terdapat perbedaan antara kelas kontrol dan eksperimen setelah diberikan perlakuan.

Sikap Ramah Lingkungan pada Kelompok Kontrol dan Eksperimen

Sikap ramah terhadap lingkungan mengacu kepada skala New Ecological Paradigm (NEP) yang memiliki lima isu utama, yaitu limits to growth, antianthropocentrism, the fragility of natures balance, rejection of exemptionalism, dan the possibility of an ecocrisis.

Uji statistik yang dilakukan menunjukkan rata-rata nilai hasil tes berdasarkan NEP-C sebelum dan sesudah perlakuan STAD dan nilai pada kelas kontrol. Nilai deskripsi statistik data pro lingkungan pada kelas kontrol dan eksperimen dapat dilihat pada tabel berikut ini:

Tabel 6. Statistik Deskriptif Data Sikap Ramah Lingkungan

\begin{tabular}{lcl}
\hline \multicolumn{1}{c}{ Data } & Mean & \multicolumn{1}{c}{ Std Dev } \\
\hline Pretest eksperimen & 61,17 & 30,86 \\
Posttest eksperimen & 86,83 & 25,19 \\
Pretest kontrol & 63,83 & 22,44 \\
Posttest kontrol & 52,17 & 15,61 \\
\hline
\end{tabular}

Hasil dari deskripsi statistik diketahui bahwa nilai pretest sikap ramah lingkungan pada kelas kontrol lebih tinggi daripada kelas ekperimen. Sedangkan pada saat posttest nilai rata-rata sikap ramah lingkungan kelas eksperimen mengalami kenaikan sedangkan pada kelas kontrol mengalami penurunan. Sebelum perlakuan STAD rata-rata nilai hasil belajar dari 33 siswa adalah sebesar 61,17 sementara setelah diberikannya perlakuan jumlah ratarata mengalami peningkatan yakni sebesar 86,83 . Akan tetapi peningkatan tidak terjadi pada kelas kontrol. Pada kelas kontrol nilai rata-rata sikap ramah terhadap lingkungan dari 63,83 turun menjadi 52,17. Untuk mengetahui lebih lanjut apakah terdapat perbedaan sikap antara sebelum dan sesudah pembelajaran STAD terhadap sikap ramah lingkungan maka dilakukan uji hipotesis. Berikut hasilnya disajikan pada tabel di bawah ini:

Tabel 7. Hasil Uji t Sikap Ramah Lingkungan

\begin{tabular}{lcccc}
\hline \multicolumn{1}{c}{ Data } & df & thitung & Sig & Ket. \\
\hline Prepost Control & 5 & 1,516 & 0,190 & Tidak \\
& & & & sig \\
Prepost Ekperimen & 5 & $-4,327$ & 0,008 & Sig \\
\hline
\end{tabular}

Berdasarkan uji statistik melalui program SPSS 19 nilai |t hitung| untuk kelas kontrol yang diperoleh adalah sebesar 1,516 dengan sig 0,190. Oleh karena sig > 0,05 maka dapat disimpulkan bahwa Ho diterima, artinya hasil NEP-C sebelum dan sesudah test pada kelas kontrol tidak terdapat perbedaan. Dengan demikian dapat dinyatakan bahwa metode pembelajaran secara konvensional pada mata pelajaran IPS yang berwawasan lingkungan belum mampu menumbuhkan sikap pro terhadap lingkungan hidup yang dimiliki oleh siswa kelas V SD Sendangadi I Sleman Yogyakarta.

Sedangkan pada kelas ekperimen diketahui nilai |t hitung| sebesar 4,327 dengan sig 0,008 . Oleh karena sig $<0,05$ maka dapat disimpulkan bahwa Ho ditolak. Artinya hasil NEP-C sebelum dan sesudah perlakuan penerapan metode pembelajaran kooperatif STAD adalah tidak sama (berbeda).

Dengan demikian dapat dinyatakan bahwa perlakuan penerapan metode pembelajaran STAD pada mata pelajaran IPS yang berwawasan lingkungan mampu menumbuhkan sikap pro terhadap lingkungan hidup yang dimiliki oleh siswa kelas V SD Sendangadi I Sleman Yogyakarta.

\section{Butir Nep Anti Lingkungan Kelas Kontrol dan Ekperimen}

Setelah diketahui nilai sikap pro lingkungan maka perlu pula untuk mengetahui bagaimana sikap anti lingkungan. Berikut ini disajikan pada tabel hasil deskripsi statistik nilai anti lingkungan:

Tabel 8. Statistik Deskriptif Data Sikap Anti Ramah Lingkungan

\begin{tabular}{lcc}
\hline \multicolumn{1}{c}{ Data } & Mean & Std Dev \\
\hline Pretest Eksperimen & 68,00 & 30,86 \\
Posttest Eksperimen & 38,75 & 25,19 \\
Pretest Kontrol & 61,50 & 22,44 \\
Posttest Kontrol & 67,50 & 15,61 \\
\hline
\end{tabular}

Hasil dari statistik deskriptif menunjukkan bahwa nilai pretest pada kelas eksperimen sebesar 68 yang mengalami penurunan saat posttest menjadi 38,75. Sedangkan nilai sikap anti ramah lingkungan pada kelas kontrol dari pretest sebesar 61,50 justru mengalami sedikit peningkatan saat test yang kedua yaitu 67,50 . Hal ini dapat diartikan bahwa pemberian metode pembelajaran dengan STAD mampu menurunkan nilai sikap anti ramah terhadap lingkungan dan menjadikan siswa menjadi le- 
bih pro terhadap ramah lingkungan. Untuk dapat menjawab hipotesis penelitian maka dilakukan pula uji t untuk sikap anti ramah lingkungan pada kelas eksperimen maupun kelas kontrol. Berikut hasilnya disajikan pada tabel di bawah ini:

Tabel 9. Hasil Uji t Sikap Anti Ramah Lingkungan

\begin{tabular}{ccccc}
\hline Data & Df & t hitung & Sig & Ket. \\
\hline Prepost Kontrol & 3 & $-0,524$ & 0,636 & Tidak \\
& & & & sig \\
Prepost Ekperimen & 3 & 3,470 & 0,040 & Sig \\
\hline
\end{tabular}

Berdasarkan uji statistik melalui program SPSS 19 nilai |t hitung| untuk kelas kontrol diperoleh sebesar 0,524 dengan sig 0,636. Oleh karena sig > 0,05 maka dapat disimpulkan bahwa Ho diterima. Artinya hasil NEP-C sebelum dan sesudah pada kelas kontrol tidak mengalami perbedaan. Sikap anti ramah terhadap lingkungan masih melekat pada diri siswa kelas kontrol.

Sedangkan hasil yang diperoleh pada kelas eksperimen $\mid t$ hitung $\mid=3,470$ dengan nilai sig $=0,040$ dimana nilai sig yang diperoleh kurang dari taraf kesalahan 5\% sehingga keputusannya adalah tolak Ho. Dengan demikian dapat dinyatakan bahwa perlakuan penerapan metode pembelajaran STAD pada mata pelajaran IPS yang berwawasan lingkungan mampu menurunkan sikap anti terhadap lingkungan hidup yang dimiliki oleh siswa kelas V SD Sendangadi I Sleman Yogyakarta.

Setelah dilakukan penelitian dan diketahui bahwa penggunaan metode pembelajaran STAD mampu mengubah siswa yang bersikap anti ramah lingkungan menjadi ramah lingkungan maka perlu dilakukan follow up. Hasil follow up ini untuk mengetahui apakah setelah pemberian perlakuan selesai siswa tetap memiliki sikap ramah lingkungan. Berikut ini hasil dari follow up berupa statistik deskriptif dan perbandingan antara nilai posttest kelas eksperimen dengan hasil follow up:

Tabel 10. Hasil Deskripsi Statistik Data Follow up

\begin{tabular}{lcccc}
\hline \multicolumn{1}{c}{ Data } & Min & Mak & Mean & $\begin{array}{c}\text { Std } \\
\text { Dev }\end{array}$ \\
\hline $\begin{array}{l}\text { Posttest Pro- } \\
\text { Lingkungan }\end{array}$ & 36 & 100 & 86,86 & 25,19 \\
$\begin{array}{l}\text { Follow up Pro- } \\
\text { lingkungan }\end{array}$ & 82 & 100 & 91,50 & 6,95 \\
$\begin{array}{l}\text { Posttest Anti- } \\
\text { lingkungan }\end{array}$ & 24 & 55 & 38,75 & 17,07 \\
$\begin{array}{l}\text { Follow Up } \\
\text { Anti-lingkungan }\end{array}$ & 9 & 45 & 30,00 & 15,87 \\
\hline
\end{tabular}

Hasil dari follow up diketahui bahwa nilai sikap terhadap ramah lingkungan semakin naik sedangkan nilai follow up pada sikap anti lingkungan semakin menurun. Hal tersebut dapat menunjukkan bahwa perlakuan yang diberikan masih memberi dampak yang positif terhadap sikap siswa di kelas V SD Sendangadi I Sleman Yogyakarta.

\section{Kesimpulan dan Saran}

Kesimpulan

Uji statistik yang dilakukan menunjukkan rata-rata nilai sikap pro lingkungan adalah sebesar 61.16 (pretes) dan mengalami peningkatan yakni sebesar 86.83 (posttes) dengan t hitung diperoleh nilai -4.327 dengan sig 0.008. Adapun nilai sikap anti lingkungan adalah sebesar 68.00 (pretes), dan sebesar 38.75 (posttes), dengan nilai $\mathrm{t}$ hitung yang diperoleh adalah sebesar 3.470 dengan sig 0.040. Dengan demikian dapat dinyatakan bahwa perlakuan penerapan model pembelajaran kooperatif tipe STAD pada mata pelajaran IPS yang berwawasan lingkungan mampu menumbuhkan sikap pro lingkungan hidup dan mengurangi sikap anti lingkungan yang dimiliki oleh siswa kelas V SD Sendangadi I Sleman Yogyakarta.

Berdasarkan hasil perhitungan uji t, dapat dilihat bahwa hasil pretes awal ditunjukkan dengan rata-rata pretes yaitu $63.91<$ ratarata hasil belajar posttest setelah eksperimen yaitu 68.03, artinya bahwa perlakuan eksperimen STAD lebih baik daripada tanpa perlakuan eksperimen. Dari perbandingan nilai $\mathrm{t}$ hitung dan $\mathrm{t}$ tabel, dapat dilihat bahwa nilai $\mathrm{t}$ hitung $-4.690<$ nilai $\mathrm{t}$ tabel $-2,036$, dengan taraf signifikan 0,000 yang $<0,05$, yang berati bahwa perlakuan eksperimen STAD yang diberikan mampu menumbuhkan sikap siswa yang ramah lingkungan. Dengan demikian, maka rumusan hipotesis yang menyatakan ada pengaruh penerapan model pembelajaran kooperatif tipe Students Team Achievement Divisions (STAD) dalam pembelajaran IPS berwawasan lingkungan untuk menumbuhkan sikap ramah lingkungan diterima, sehingga dapat disimpulkan bahwa terdapat pengaruh yang positif penerapan model pembelajaran kooperatif tipe STAD dalam pembelajaran IPS berwawasan lingkungan untuk menumbuhkan sikap ramah lingkungan di SD Sendangadi 1 Mlati Sleman Yogyakarta semester II Tahun 2011 / 2012". 
Saran

Perlunya penggunaan model pembelajaran kooperatif tipe STAD (Students Team Achievement Division) dalam Pembelajaran IPS Berwawasan Lingkungan untuk mengembangkan sikap ramah lingkungan untuk segera disosialisasikan secara lebih luas kepada para guru.

Para guru perlu memiliki keterampilan sebagai bekal untuk menciptakan pembelajaran yang efektif dan menyenangkan.

Perlunya dilakukan penelitian lebih lanjut dan lebih luas sebagai pengembangan dari penelitian ini.

\section{Daftar Pustaka}

Efrat, E., \& Tamar, T. (2012). Environmental attitudes and environmental behaviorwhich is the horse and which is the cart? Sustainability 2012, 4, diunduh dari www.mdpi.com/journal/sustainability pada tanggal 31 Oktober 2012.

Mahanal, dkk. (2009). Pengaruh pembelajaran project based learning (PjBL) pada materi ekosistem terhadap sikap dan hasil belajar siswa SMAN 2 Malang. Skripsi. Malang: FMIPA Universitas Negeri Malang.

Mason et al. (2000). The link between attractiveness of extrabrand attributes and the adoption of inovations. Journal of Academy of Marketing Science. 27: 306-319.

Nisfiannoor. (2009). Pendekatan statististika modern untuk ilmu sosial. Jakarta: Salemba Humanika.
Roestiyah. (2001). Strategi belajar mengajar. Jakarta: Rineka Cipta.

Roy Killen. (2006). Effective teaching strategies: Lessons from research and practice. USA: Thompson.

Saifuddin Azwar. (2005). Sikap manusia: teori dan pengukurannya. Yogyakarta: Pustaka Pelajar.

Siti Partini. (1995). Psikologi perkembangan. Yogyakarta: FIP IKIP Yogyakarta.

Slavin, R. E. (2005). Pembelajaran kooperatif: teori, riset dan praktik. terjemahan Lita. Bandung: Nusa Media.

Sugiyono. (2007). Metode penelitian kuantitatif, kualitatif, $R \& D$. Bandung: Alfabeta.

Suranto \& Kusrahmadi, S. D. (2003). Upaya pembinaan kepedulian lingkungan hidup. Cakrawala Pendidikan. Edisi khusus Dies Natalis. Jakarta: UNJ.

Sutrisno Hadi. (2004). Metode research. Yogyakarta: Andi Offset.

Tamat, Tisnowati dan Moekarto Mirman. (2005). Pendidikan jasmani dan kesehatan. Jakarta: Universitas Terbuka.

Tim, G., Gail, L. J. (2005). Teaching green: the elementary years: Hands-on learning in grades $K-5$. Canada: New society publisher.

Udin S Winataputra. (2009). Materi dan pembelajaran IPS SD. Jakarta: Universitas Terbuka 